\title{
Chemical and Biological Significance of Naturally Occurring Additives on African Black Soap and its Performance
}

\section{IKOTUN, A. ADEBOMI; OGUNDELE, O. FISAYO; KAYODE, O. MOBOLAJI; *AJAELU, C. JOHN}

\author{
Department of Chemistry and Industrial Chemistry, Bowen Univeristy, Iwo, Nigeria \\ *Corresponding author's email: ajaelujohn46@gmail.com
}

\begin{abstract}
The potassium ester $\left(\mathrm{C}_{11} \mathrm{H}_{23} \mathrm{COO}^{-} \mathrm{K}^{+}\right)$commonly known as African black soap was prepared by the action of palm kernel oil on cocoa pods. This was divided into four portions. Sample A contained the African Black soap without any modification, sample B was black soap modified with honey, sample C and sample D were modified with shear butter and coconut oil respectively. The $\mathrm{pH}$, FTIR and phytochemical analyses of the samples were carried out. They were also screened for in-vitro antibacterial activities against two Gram-positive bacteria (Staphylococcus aureus and Bacillus subtilis) and two Gram-negative bacteria (Pseudomonas aeruginosa and Escherichia coli). The $\mathrm{pH}$ determinations showed that all the samples were alkaline in nature with sample A having the lowest $\mathrm{pH}$ of 8.90 , while sample B had the highest $\mathrm{pH}$ of 9.58. FTIR analyses of sample A revealed strong bands assigned to the $v(\mathrm{C}=\mathrm{O})$ frequency of a keto group at 1668 and $1560 \mathrm{~cm}^{-1}$ and a strong band at $1379 \mathrm{~cm}^{-1}$ assigned to the $v(\mathrm{C}-\mathrm{O})$ frequency of the ester oxygen. The spectra of samples B, C and D showed no complexation through these oxygen donor atoms, but rather some interactions with other present molecules. Phytochemical analyses showed that samples A and D were rich in saponin, all the samples were rich in both flavonoids and terpenoids, while tannins and steroids were absent in all the samples. Antimicrobial studies showed that only sample B was active against Staphylococcus aureus, while samples $\mathrm{A}, \mathrm{C}$ and $\mathrm{D}$ were inactive against all tested microorganisms.

https://dx.doi.org/10.4314/jasem.v21i7.27
\end{abstract}

Copyright @ 2017 Ikotun et al. This is an open access article distributed under the Creative Commons Attribution Non-Commercial License (CC-BY-NC), which permits unrestricted use, distribution, and reproduction in any medium, provided the original work is properly cited.

Received 13 August 2017, received in revised form 22 October 2017, accepted 30 November 2017.

Key words: Additives, African Black Soap, Phytochemical and Antimicrobial

Soaps are cleaning agents that are usually made by reacting alkali with naturally occurring fat or fatty acids. The traditional African Black soap which has in combination, water, roasted plantain skin or cocoa pod, palm oil, palm kernel oil, or Shea butter, when put together, are collectively referred to as "black soap". African Black soap or black soap is a natural source of vitamin A and E, and iron (Grieve, 1997). Black soap made with Shea butter offers protection against UV rays while black soap made with plantains contains a high concentration of iron along with vitamins A and E (Treehugger, 2008). The attribute of the soap includes gentleness on the skin, rich lather, protection against skin disorders (including rashes, eczema, scabies) treatment of skin infection (such as ringworm), protection of even skin toning and smoothness of the skin (Getradeghana, 2000). The lauric acid content of palm kernel oil has the additional beneficial function of being formed into monolaurin in human or animal body (Emg, 2000). This means that palm kernel oil might have some potent antimicrobial effect in-vivo. The palm kernel oil sample which had the highest lauric acid value had the highest effect on Staphylococcus aureus, Streptococcus $s p$ and C. albicans. This confirmed that lauric acid is the antimicrobial agent in palm kernel oil (Ugbogu, 2006). Staphylococcus aureus and Streptococcus sp. which cause skin and wounds infections are inhibited minimally by palm kernel oil. Although the antimicrobial activity observed is low, Kabara (1978) has shown that the use of this type of inhibitory agent does not lead to the development of resistant organisms. Shea butter is the fat extracted from the kernels of Vitellariaparadoxa. Shea butter contains high level of UV-B absorbing triterpenes esters including cinnamic acid, tocopherols (Vitamin A) and phytosterols. Analysis of the kernel reveals the presence of phenolic compounds such as garlic acid, catechin, epicatechnin, gallate as well as quercetin and transcinnamic acid (Steven et al., 2003), some of which are known to have antimicrobial activities. In this study we made use of palm kernel oil to produce black soap. The soap was thereafter modified with honey, shea butter and coconut oil. In addition, the $\mathrm{pH}$, FTIR, phytochemical screening and antimicrobial screenings were carried out. We have previously reported the physicochemical analyses of black soap and its modifications with some organic compounds, as well as that of its first known transition metal complexes (Ikotun et al., $2017 \mathrm{a}, \mathrm{b}$ ). We hereby report the significance of African black soap, the effects of its modifications with some commonly used natural products, as well as the 
chemistry and biological importance of such modifications.

\section{MATERIALS AND METHODS}

Chemical: Palm kernel oil was purchased from the local market, while cocoa pods were locally sourced for at a town called Ifeodan, Osun State, Nigeria. All other chemicals and solvents were purchased as analytical grades from Sigma-Aldrich and SAARChem and were used without further treatments.

Instrumentation: The functional groups on the surface of the African black soap were analyzed by Fourier Transform Infrared Spectrophotometer, Nicolet Avatar FTIR 330. Spectroscopic grade $\mathrm{KBr}$ was used, and the spectra were recorded from 4000 $\mathrm{cm}^{-1}$ to $500 \mathrm{~cm}^{-1}$.

Preparation of African black soap: The procedure previously reported (Ikotun et al., 2017a) was employed for the preparation of black soap with little modifications. 20 pieces of cocoa pods were sundried and roasted into ash in a pot. $1 \mathrm{~L}$ of water was added to the ash. This was thoroughly mixed and sieved to obtain the filtrate. The filtrate was boiled for about 2-3 hours until a very dark colour was obtained. It was then cooled at room temperature. $240 \mathrm{ml}$ of the palm kernel oil was measured into a different pot and heated mildly until it melted. $120 \mathrm{ml}$ of the ash filtrate was added, a little quantity at a time, into the hot oil and stirred continuously until it solidified. $5 \mathrm{ml}$ of palm kernel oil was then added to the soap and heated for 5 minutes to soften it after which the soft soap was allowed to cool at room temperature. After cooling, the soap was then divided into four portions. Different naturally occurring beauty enhancing organic compounds were added as additives into three of the soap portions in separate containers. Sample A contained the black soap without any additive, To samples B, C and D were added appropriate amounts of honey, shea butter and coconut oil respectively. The prepared unmodified and modified black soaps were left for about three days in the mold in order to solidify. The finished product was soft and really malleable.

Antimicrobial Test $: 15.2 \mathrm{~g}$ of Mueller Hinton agar was measured into a $500 \mathrm{ml}$ conical flask, $400 \mathrm{ml}$ of distilled water was added and mixed/shaken till it dissolved, it was then covered with cotton wool, and aluminum foil paper and labeled. It was autoclaved at a temperature of $121^{\circ} \mathrm{C}$ for 15 minutes. The agar was allowed to cool to a temperature of $45{ }^{\circ} \mathrm{C}$ and aseptically poured into sterile Petri dishes. This was allowed to solidify in the Petri dishes. $0.5 \mathrm{~g}$ of each of the prepared soap samples was weighed into Mac Cartney bottles and $2.5 \mathrm{ml}$ of distilled water was added for dissolution. A sterile filter paper disc (7 $\mathrm{mm}$ in diameter) was then placed inside the dissolved soap mixture and allowed to soak for 10 minutes. The plates were then inoculated with the test bacteria using the spread plate method with a sterile swab stick. The test bacteria were Staphylococus aureus, Escherichia coli, Bacilus sp., and Pseudomonas aeruginosa. The inoculated plates were kept on the work bench for 1 hour before further work was carried out. The soaked discs were picked using forceps sterilized by flaming and placed aseptically on the inoculated Petri dishes. The discs were allowed to stick on to the surface of the agar medium before incubations. The plates were incubated at 37 ${ }^{\circ} \mathrm{C}$ for 24 hours and antibacterial activity of the soap was measured as diameter of zones of inhibition surrounding the impregnated filter paper discs. Zones of inhibition were measured in mm (Bauer et al., 1966, Balogun and Owoseni., 2013).

\section{RESULTS AND DISCUSSIONS}

pH Determination: Table 1 shows the $\mathrm{pH}$ values for the various black soaps produced. All the soaps produced have alkaline $\mathrm{pH}$. Sample A (without any additive) has the lowest alkaline $\mathrm{pH}$ of 8.90 . Addition of honey, shea butter and coconut oil increased the pH to $9.58,9.56$ and 9.00 respectively. Gfatter et al. (1997) produced alkaline soap of $\mathrm{pH} 9.50$. Tarum et al. (2014) stated that majority of soaps have a $\mathrm{pH}$ of 9-10.

Phytochemical Screening: The results of the phytochemical screenings of the untreated (sample A) and modified African black soaps (samples B, C, D) are presented as Table 2. This shows that only Samples A and D are rich in Saponin. All the samples are rich in both flavonoids and terpenoids. Tannins and Steroids are absent in all the samples.

Infrared Spectra Analyses: The FTIR spectrum of the African black soap (Sample A) has already been reported (Ikotun et al., 2017 b). Therefore, the data has been used as the reference for analyzing those for samples B, C and D (Figures 1, 2 and 3 respectively). The results of these analyses have been presented as Table 3. The characteristic vibrational frequencies have been identified by comparing the spectra of the prepared African black soap with the modified samples (Ikotun et al., 2017 a, b). Two potential donor sites have been identified in black soap. These are the keto-oxygen and the ester oxygen. The strong and broad band at $3345 \mathrm{~cm}^{-1}$ in sample A was assigned to the stretching vibration of $\mathrm{OH}$. This band has shifted to a higher frequency of $3404 \mathrm{~cm}^{-1}$ in 
Sample B, but shifted to lower frequencies of 3335 and $3300 \mathrm{~cm}^{-1}$ in Samples C and D respectively. Sample A has two strong bands and a shoulder band due to $\mathrm{sp}^{3} \mathrm{C}-\mathrm{H}$ stretching vibrations at $2918 \mathrm{~cm}^{-1}$,
$2851 \mathrm{~cm}^{-1}$ and $2957 \mathrm{~cm}^{-1}$ respectively. Equation 1 shows the reaction for the production of African black soap as reported by Dunn (2011).

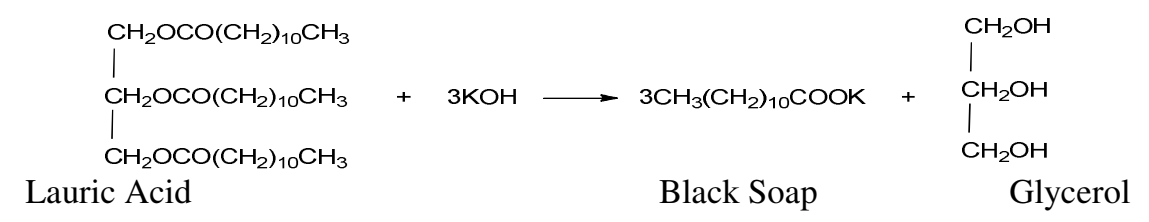

Equation 1: Preparation of African Black Soap

Table 1: $\mathrm{pH}$ values of unmodified (Sample A) and modified (Samples B, C, and D) black soaps

\begin{tabular}{|c|c|c|c|}
\hline SAMPLE & & ADDITIVES & pH \\
\hline $\mathbf{A}$ & & Black Soap without additive & 8.90 \\
\hline B & & Honey & 9.58 \\
\hline C & & Shea butter & 9.56 \\
\hline & D & Coconut oil & 9.00 \\
\hline
\end{tabular}

Table 2: Phytochemical screening on the soap samples

\begin{tabular}{clllll}
\hline Samples & Tannins & Saponin & Flavonoids & Steroids & Terpenoids \\
\hline A & - & + & + & - & + \\
B & - & - & + & - & + \\
C & - & - & + & - & + \\
D & - & + & + & - & + \\
\hline
\end{tabular}

Note: + Presence of chemical compound; - Absence of chemical compound

These bands have remained almost unchanged in all the modified samples. The stretching vibrational frequency of $\mathrm{C}=\mathrm{O}$ for sample $\mathrm{A}$ appeared as strong bands at $1668 \mathrm{~cm}^{-1}$ and $1560 \mathrm{~cm}^{-1}$. These shifted to a lower and slightly higher frequencies of 1653 and $1562 \mathrm{~cm}^{-1}, 1665$ and $1562 \mathrm{~cm}^{-1}$, as well as 1653 and $1564 \mathrm{~cm}^{-1}$ for samples B, C and D respectively. These only signify the interactions of the keto oxygen with some other present molecules (Ikotun et al., $2017 \mathrm{~b}$ ). The stretching vibrational frequency of $\mathrm{C}-\mathrm{O}$ in the spectrum of sample A appeared as a strong band at $1379 \mathrm{~cm}^{-1}$ (Ajaelu et al., 2015). This band appeared barely unchanged in samples $\mathrm{C}$ and $\mathrm{D}$, but shifted to a lower frequency of $1373 \mathrm{~cm}^{-1}$ in sample B. Antimicrobial Studies: Antimicrobial tests were carried out and the results are presented in Table 4. This shows that of all the black soap samples, only sample B had little effect on Staphylococcus aureus.

Table 3: FTIR spectra analyses of the metal complexes and black soap

\begin{tabular}{|c|c|c|c|c|c|}
\hline Compounds & $\begin{array}{l}\mathrm{v}(\mathrm{OH}) \\
\left(\mathrm{cm}^{-1}\right)\end{array}$ & $\begin{array}{l}v(\mathrm{C}-\mathrm{H}) \\
\left(\mathrm{cm}^{-1}\right)\end{array}$ & $\begin{array}{l}v(\mathrm{C}=\mathrm{O}) \\
\left(\mathrm{cm}^{-1}\right)\end{array}$ & $\begin{array}{l}v(\mathrm{C}-\mathrm{O}) \\
\left(\mathrm{cm}^{-1}\right)\end{array}$ & Others \\
\hline Sample A & $3345 \mathrm{bs}$ & $\begin{array}{l}2918 \mathrm{~s} \\
2851 \mathrm{~s} \\
2957 \mathrm{sh}\end{array}$ & $\begin{array}{l}1668 \mathrm{~s} \\
1560 \mathrm{~s}\end{array}$ & $1379 \mathrm{~s}$ & $1416 \mathrm{~s}$ \\
\hline Sample B & $3404 \mathrm{bs}$ & $\begin{array}{l}2918 \mathrm{~s} \\
2851 \mathrm{~s} \\
2957 \mathrm{sh}\end{array}$ & $\begin{array}{l}1653 \mathrm{~m} \\
1562 \mathrm{~s}\end{array}$ & $1373 \mathrm{~s}$ & $\begin{array}{l}1404 \mathrm{~s} \\
1373 \mathrm{ml}\end{array}$ \\
\hline Sample C & $3335 \mathrm{bm}$ & $\begin{array}{l}2918 \mathrm{~s} \\
2850 \mathrm{~s}\end{array}$ & $\begin{array}{l}1665 \mathrm{~m} \\
1562 \mathrm{~s}\end{array}$ & $1379 \mathrm{~s}$ & $\begin{array}{l}1416 \mathrm{~s} \\
1471 \mathrm{sh}\end{array}$ \\
\hline Sample D & $3300 \mathrm{bs}$ & $\begin{array}{l}2918 \mathrm{~s} \\
2851 \mathrm{~s} \\
2957 \mathrm{sh}\end{array}$ & $\begin{array}{l}1653 \mathrm{~s} \\
1564 \mathrm{~s}\end{array}$ & $1379 \mathrm{~s}$ & $\begin{array}{l}1416 \mathrm{~s} \\
1471 \mathrm{sh}\end{array}$ \\
\hline
\end{tabular}

Note: $\mathbf{s}$ - strong, $\mathrm{m}$ - medium, b - broad, bs - broad strong, bm - broad medium, sh - shoulder

Table 4: Antibacterial activities of the black soap samples

\begin{tabular}{clllll}
\hline Samples & $\begin{array}{l}\text { Escherichia coli } \\
(\mathrm{mm})\end{array}$ & $\begin{array}{l}\text { Bacillus subtilis } \\
(\mathrm{mm})\end{array}$ & Pseudomonas aeruginosa $(\mathrm{mm})$ & $\begin{array}{l}\text { Staphylococcus } \\
(\mathrm{mm})\end{array}$ & aureus \\
\hline A & - & - & - & - \\
B & - & - & - & $10^{*}$ \\
C & - & - & - & - \\
D & - & - & - & - & \\
\hline \multicolumn{7}{r}{} \\
\hline
\end{tabular}




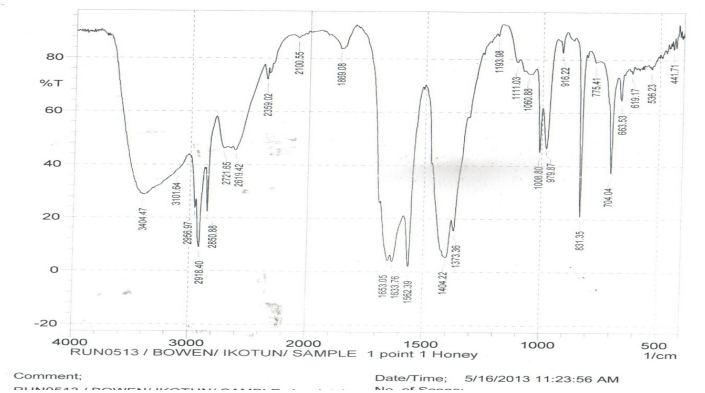

Fig 1: FTIR of black soap sample B (modified with honey)

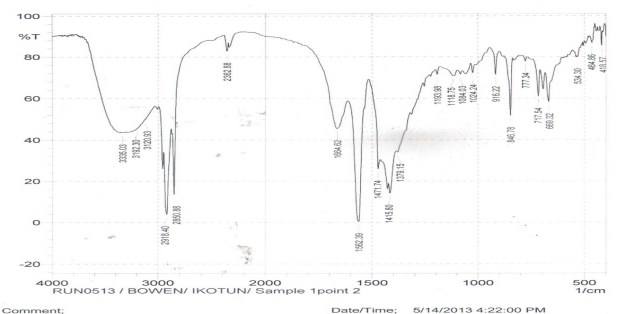

Fig 2: FTIR of black soap sample C (modified with Shear Butter)

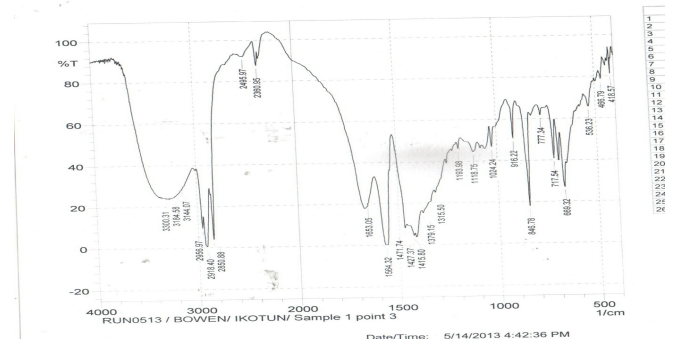

Fig 3: FTIR of black soap sample D (modified with Coconut Oil)

Conclusion: The prepared African Black soap was mixed in separate vials with honey, shea butter and coconut oil respectively. The results of the chemical analyses of these samples showed that the addition of these naturally beautifying compounds to black soap has not denatured it chemically, but rather it has even aided its antibacterial activities.

Acknowledgement: The authors acknowledge the assistance of Dr. Abimbola A. Owoseni towards the success of the antimicrobial studies of the prepared samples.

\section{REFERENCES}

Al Durtschi: http://waltonfeed.com/old/soap/soap.html, 2000.

Ajaelu, CJ; Atolaiye, BA.; Ibironke, OA (2015). J. Chem. Pharm. Res. 7 (12): 605-617.
Balogun, OS; Owoseni, AA (2013). Phytochemical and antimicrobial investigation of Dissotis rotundifolia (sm) Triana. Nat. Prod. 9 (2): 77-80.

Bauer, AW; Kirby, WM; Sherris, JC; Turck, M (1996). Antibiotic susceptibility testing by a standardized single disk method. American J. Clin. Pathol. 45: 439496.

Dunn, KM (2010). Scientific Soap making: The Chemistry of Cold Process, Clavicula Press.

Emg, MG (2000). Lauric oils as antimicrobial agents CRC press London Pp. 81-87.

Getradeghana, BT (2000). Evaluation of African traditional soap. Global J. Pure Appl. Sc. 6:174-179.

Gfatter R; Hackl P; Braun F (1997). Effects of soap and detergents on skin surface $\mathrm{pH}$, stratum corneum hydration and fat content in infants. Dermatol. 195(3): 258-62.

Grieve, M (1997). Modern Herbal Medicine, $1^{\text {st }}$ edition, Saunders Company Limited. Pg 64-74.

Ikotun, AA; Awosika, OO; Oladipupo MA (2017 a). The African Black soap from Elaeisguinensis (Palm Kernel Oil) and Theobroma cacao (Cocoa) and its transition metal complexes. Afr. J. Biotechnol. 16 (18): 10421047.

Ikotun, AA; Olalere, C. A; Adekunle, DO; Dawodu, MO (2017 b). Phtochemistry and Antibacterial Studies of African Black Soap and its Modified Samples. J. Chem. Pharm. Res. 9 (5): 354-359.

Kabara, JJ (1978). Health oils from the tree of life, in pharmacological effects of lipids. AOCS press London. Pp. 624-629

Popoola, L (2005). Poverty and Economical Viability of Neem tree Growing in Nigeria. A Seminar presented at a workshop organized by Central Bank of Nigeria, Katsina State, Nigeria.

Tarum J; Susan J; Suria J; Susan V. J; Criton S (2014). Evaluation of $\mathrm{pH}$ of Bathing Soaps and Shampoos for Skin and Hair Care. Indian J. Dermatol. 59 (5): 442444.

Treehugger. (2008): What is Black Soap? http//www.treehugger.com/style/what-is-black-soap.html.

Ugbogu, OC (2006). Lauric acid content and inhibitory effect of palm kernel oil on two bacterial isolates and C. Albicans. Afr. J. Biotechnol. 5(11): 1045-1047. 